\title{
Comparison of different fertilizer management practices on rice growth and yield in the Ashanti region of Ghana
}

\author{
Roland Nuhu Issaka ${ }^{1}$, , Moro Mohammed Buri ${ }^{1}$, Satoshi Nakamura ${ }^{2}$, Satoshi Tobita ${ }^{2}$ \\ ${ }^{1}$ CSIR-Soil Fertility and Plant Nutrition Division, Soil Research Institute, Academy Post Office, Kwadaso, Ghana \\ ${ }^{2}$ Crop Production and Environment Division, Japan International Research Center for Agricultural Sciences. Ohwashi, Tsukuba, 305-8686, \\ Japan
}

\author{
Email address: \\ rolandissaka@yahoo.com (Issaka R. N.), moro_buri@yahoo.com (Buri M. M.), nsatoshi@affrc.go.jp (Nakamura S.), \\ bita1mon@jircas.affrc.go.jp (Tobita S.)
}

\section{To cite this article:}

Roland Nuhu Issaka, Moro Mohammed Buri, Satoshi Nakamura, Satoshi Tobita. Comparison of Different Fertilizer Management Practices on Rice Growth and Yield in the Ashanti Region of Ghana. Agriculture, Forestry and Fisheries. Vol. 3, No. 5, 2014, pp. 374-379.

doi: 10.11648/j.aff.20140305.17

\begin{abstract}
Nutrient management is critical in increasing and sustaining rice yield. A field experiment was conducted to examine the effects of inorganic fertilizer (IF), poultry manure (PM) and their combinations on rice yield and possible residual effects. A randomized complete block design with three replications was used and the trial was conducted on a Gleysol. In 2011 SPAD values for IF and PM/ IF combinations (except 2.0 t/ha PM + 22.5-15-15 kg N: $\mathrm{P}_{2} \mathrm{O}_{5}$ : $\mathrm{K}_{2} \mathrm{O} /$ ha) were significantly higher in the sixth week onwards than PM. Number of panicles/plant and number of panicles $\mathrm{m}^{2}$ were significantly higher for 90-60-60 kg N: $\mathrm{P}_{2} \mathrm{O}_{5}: \mathrm{K}_{2} \mathrm{O} / \mathrm{ha}$ and 2.0 t/ha $\mathrm{PM}+22.5-15-15 \mathrm{~kg} \mathrm{~N}: \mathrm{P}_{2} \mathrm{O}_{5}: \mathrm{K}_{2} \mathrm{O} / \mathrm{ha}$ than 6.0 and 4.0 t/ha PM resulting in significantly higher grain yield. Grain yield of IF was similar to grain yield of PM/IF combinations. In 2012 the residual effects showed a significantly higher SPAD value for the $6.0 \mathrm{t} / \mathrm{ha} \mathrm{PM}$. Also $6.0 \mathrm{t} / \mathrm{ha} \mathrm{PM}, 4.0 \mathrm{t} / \mathrm{ha} \mathrm{PM}$ and $4.0 \mathrm{t} / \mathrm{ha} \mathrm{PM}+30 \mathrm{~kg} \mathrm{~N} / \mathrm{ha}$ had significantly high number of panicles/plant and number of panicles $/ \mathrm{m}^{2}$ than IF. Residual effect of PM applied at $4.0 \mathrm{t} / \mathrm{ha}$ and above gave significantly higher grain yield than IF. Mean grain yield for the three years showed that $4.0 \mathrm{t} / \mathrm{ha} \mathrm{PM}+30 \mathrm{~kg}$ $\mathrm{N} / \mathrm{ha}$ and $2.0 \mathrm{t} / \mathrm{ha} \mathrm{PM}+22.5-15-15 \mathrm{~kg} \mathrm{~N}: \mathrm{P}_{2} \mathrm{O}_{5}: \mathrm{K}_{2} \mathrm{O} /$ ha gave significantly higher yields than the other treatments. The results indicate that integrating IF and PM is a better option in increasing and sustaining rice production.
\end{abstract}

Keywords: Grain Yield, Inorganic Fertilizer, Poultry Manure, Rice

\section{Introduction}

Rice production in Ghana faces several challenges, notably water shortage, low soil fertility and poor soil and water management [1]. Several authors have identified low inherent soil fertility as a major cause for low rice yield $[2 ; 3 ; 4 ; 1 ; 5]$ in Ghana. The problem is compounded as farmers are not able to purchase adequate amounts of mineral fertilizer (high cost) and rely mostly on natural soil fertility which is low and declining. Rice yield can vary from less than $1.0 \mathrm{t} / \mathrm{ha}$ to as high as $6.0 \mathrm{t} / \mathrm{ha}$ due to variation in both water and soil fertility management [3 and 1].

The availability of large amounts of organic materials in Ghana [6] can be harnessed to improve rice production in the country. Organic materials available for usage include poultry manure, cow dung, rice straw and human excreta. [4] observed that application of 7.0 t/ha cow dung gave similar yield as sole mineral fertilizer. The authors also reported that application of $3.5 \mathrm{t} / \mathrm{ha}$ cow dung + half rate of mineral fertilizer gave similar effect as full rate of mineral fertilizer.

According to [7] cited by [8], organic materials are fundamentally important in that they supply various kinds of plant nutrients including micronutrients, improve soil physical and chemical properties and hence nutrient holding and buffering capacity, and consequently enhance microbial activity. In addition, organic matter slowly but continuously releases $\mathrm{N}$ as plant need it. $\mathrm{N}$ is the most limiting nutrient in irrigated rice systems, $\mathrm{P}$ and $\mathrm{K}$ deficiencies also reduce rice yield under continuous cultivation particularly in the inland valleys [4].

Many researchers including [9], reported that the effects of organic matter application can be observed after 3 to 5 years. A good residual effect ensures good soil health and sustains productivity over a longer period of time compared to mineral fertilizer. 
To ensure that the fertility of the soil is improved, it is imperative to find cheaper alternatives which can be used solely or in combination with mineral fertilizer. In this study poultry manure, sole or in combination with mineral fertilizer was evaluated for its potential to improve and sustain rice production.

\section{Materials and Methods}

Experimental site and design: The experiment was conducted at the Central Agricultural Station, Kwadaso (Latitude 6o 40' 59" and Longitude 1037'0") in 2010 and repeated in 2011 and 2012. The soils are gleysols, developed over granite [10]. A Randomized Complete Block design with 3 replications was used. Jasmine 85 was used as the test crop in 2010 while TOX 3108-56-4-4-2 (Sikamo-local name) was planted in 2011 and 2012. Two seedlings were transplanted per hill at $20 \times 20 \mathrm{~cm}$. Treatments and times of application are presented in Table 1. Poultry manure (PM) was broadcast and incorporated into the soil a week before transplanting.

Table 1. Treatment combinations in 2010 and 2011.

\begin{tabular}{lll}
\hline Treatment & Basal Application (1WAT) & Top Dressing (5 WAT) \\
\hline 6 t/ha PM & - & \\
4 t/ha PM & - & $30 \mathrm{~kg} \mathrm{~N} / \mathrm{ha}$ \\
4 t/ha PM $+30 \mathrm{~kg} \mathrm{~N} / \mathrm{ha}$ & - & $30 \mathrm{~kg} \mathrm{~N} / \mathrm{ha}$ \\
2 t/ha PM $+30 \mathrm{~kg} \mathrm{~N} / \mathrm{ha}$ & - & $20 \mathrm{~kg} \mathrm{~N} / \mathrm{ha}$ \\
2 t/ha PM $+22.5-15-15 \mathrm{~kg} \mathrm{~N}: \mathrm{P}_{2} \mathrm{O}_{5}: \mathrm{K}_{2} \mathrm{O} / \mathrm{ha}$ & All P\&K $+10 \mathrm{~kg} \mathrm{~N} / \mathrm{ha}$ & $60 \mathrm{~kg} \mathrm{~N} / \mathrm{ha}$ \\
$90-60-60 \mathrm{~kg} \mathrm{~N}: \mathrm{P}_{2} \mathrm{O}_{5}: \mathrm{K}_{2} \mathrm{O} / \mathrm{ha}$ & All P\&K $+30 \mathrm{~kg} \mathrm{~N} / \mathrm{ha}$ & \\
\hline
\end{tabular}

WAT: weeks after transplanting

In 2012, the residual effects of the various treatments were evaluated. $30 \mathrm{~kg} \mathrm{~N} / \mathrm{ha}$ was applied to all plots. The field was designed according to the "sawah" system (plots were bunded, ploughed, puddled and leveled with inlets and outlets for supplementary irrigation and drainage when necessary).

\subsection{Soil Sampling and Analysis}

Initial soil samples were taken $(0-20 \mathrm{~cm})$ before the field layout was done. Soil samples were brought to Soil Research Institute laboratory and air-dried at room temperature. The air-dried soil samples were ground and passed through $2 \mathrm{~mm}$ sieve. Soil $\mathrm{pH}$ was measured using a glass electrode ( $\mathrm{pH}$ meter) in a soil to water ratio of 1:2.5 [11]. Organic carbon was determined by the wet combustion method [12]. Total nitrogen was determined by micro Kjeldahl method [13] and available phosphorus according to [14] Exchangeable cations (Ca, Mg, $\mathrm{K}$ ) were extracted with $1.0 \mathrm{M}$ ammonium acetate solution and determined by atomic absorption spectrometry [15]. Exchangeable acidity was determined first by extracting it with $\mathrm{KCl}$ and titrating the extract with sodium hydroxide [15]. Effective cation exchange capacity was determined by the addition of all the cations.

\subsection{Plant Growth Characteristics}

Soil and plant analysis development (SPAD) value was measured weekly up to the eighth week. SPAD value was measured using a chlorophyll meter (SPAD-502, Konica Minolta Sensing Inc., Osaka, Japan). Measurement of SPAD value was done on the youngest fully expanded leaf. Number of panicles per plant and plant height were recorded at maturity.

\subsection{Dry Matter and Grain Yield}

At maturity, an area of $2.0 \mathrm{~m}^{2}$ per treatment was demarcated and harvested. Yield components (grain and stover) were measured and yield per hectare estimated. The statistical software, Statistics 8, was used for data analysis. Standard error was used as the mean separator.

\section{Results and Discussion}

\subsection{Soil and Poultry Manure Properties}

Initial soil properties for the site are presented in Table 2. Exchangeable cations are very low reflecting a low effective cation exchangeable capacity. The soil is strongly acidic. Both organic matter and available phosphorus are also low.

The nutrient content of the poultry manure used is shown in Table 3. The manure was collected from a farm within the district in which the experiment was conducted. The manure was collected from laying birds hence the high values for calcium and magnesium.

Table 3. Nutrient content of poultry manure.

\begin{tabular}{lllll}
\hline Total N & P & K\% & Ca & Mg \\
\hline 2.6 & 0.61 & 1.10 & 8.50 & 7.00 \\
\hline
\end{tabular}

\subsection{0}

\subsubsection{Yield Components}

In 2010 plant height, number of panicles/plant and grain yield for all the treatments were similar (Table 4). Jasmine 85 normally gives up to $5.0 \mathrm{t} / \mathrm{ha}$ grain yield or more under good environment and recommended fertilization. However, the experimental field experienced a severe attack of blast and the disease was finally brought under control after 2 weeks of spraying with fungicide. This probably masked the effect of the various treatments and also resulted in grain yield reduction.

\subsection{1}

\subsubsection{Effect of Treatments on SPAD Values}

Figure 1 shows changes in SPAD values in 2011. SPAD values increased significantly for all the treatments up to the second week. SPAD value for the 90-60-60 kg N: $\mathrm{P}_{2} \mathrm{O}_{5}$ : 
$\mathrm{K}_{2} \mathrm{O}$ /ha treatment increased significantly over all the other treatments in the third week but declined steadily during the fourth and fifth week. SPAD value for this treatment again increased significantly to above 45 after $60 \mathrm{~kg} \mathrm{~N} / \mathrm{ha}$ was applied in the fifth week. $4.0 \mathrm{t} / \mathrm{ha} \mathrm{PM}+30 \mathrm{~kg} \mathrm{~N} / \mathrm{ha}$ and 2.0 $\mathrm{t} / \mathrm{ha} \mathrm{PM}+30 \mathrm{~kg} \mathrm{~N} / \mathrm{ha}$ treatments showed similar trend as 90-60-60 kg N: $\mathrm{P}_{2} \mathrm{O}_{5}: \mathrm{K}_{2} \mathrm{O} / \mathrm{ha}$. SPAD values for sole PM at 6.0 $\mathrm{t} / \mathrm{ha}$ and $4.0 \mathrm{t} / \mathrm{ha}$ showed a decline from above 40 in the second week to below 40 in the eighth week. The amount of nitrogen and rate of mineralization when PM was applied at $6.0 \mathrm{t} / \mathrm{ha}$ was probably not enough to provide adequate amounts of nitrogen for the plants in the eighth week hence the decline in SPAD value. According to [8], SPAD value is the most important growth character. The SPAD value reflects nutrient (especially nitrogen) availability in the soil and its influence on plant growth. Thus high nitrogen content in the 90-60-60 kg N: P2O5: K2O/ha treatment largely explains why SPAD values are generally higher for the $90-60-60 \mathrm{~kg} \mathrm{~N}$ : P2O5: $\mathrm{K} 2 \mathrm{O} / \mathrm{ha}$ treatment followed by $4.0 \mathrm{t} / \mathrm{ha} \mathrm{PM}+30 \mathrm{~kg} \mathrm{~N} / \mathrm{ha}$ and $2.0 \mathrm{t} / \mathrm{ha} \mathrm{PM}+30 \mathrm{~kg} \mathrm{~N} / \mathrm{ha}$ treatments. Lower SPAD values for 6.0 t/ha PM, 4.0 t/ha PM and 2.0 t/ha PM+ 22.5-15-15 kg N: $\mathrm{P} 2 \mathrm{O} 5: \mathrm{K} 2 \mathrm{O} / \mathrm{ha}$ is partially due to lower amount of $\mathrm{N}$ available for the growing plants.

\subsubsection{Yield Components and Grain Yield}

In 2011 plant height was similar for all the treatments (Table 5). Number of panicles/plant however varied significantly between treatments. Sole poultry manure applied at $6.0 \mathrm{t} / \mathrm{ha}$ and $4.0 \mathrm{t} /$ ha gave plants with lower number of tillers/plant than sole mineral fertilizer and $2 \mathrm{t} / \mathrm{ha} \mathrm{PM}+22.5-15-15 \mathrm{~kg} \mathrm{~N}$ : P2O5: $\mathrm{K} 2 \mathrm{O} / \mathrm{ha}$ (Table 5) probably due to initial slow release of nutrients during tillering. Number of panicles $/ \mathrm{m}^{2}$, stover and grain yields are also presented in Table 5. Number of panicles $/ \mathrm{m}^{2}$ were significantly higher under 90-60-60 and 2.0 t/ha $\mathrm{PM}+22.5-15-15 \mathrm{~kg} \mathrm{~N}: \mathrm{P}_{2} \mathrm{O}_{5}: \mathrm{K}_{2} \mathrm{O} /$ ha than PM applied at $2.0 \mathrm{t} / \mathrm{ha}+30 \mathrm{~kg} \mathrm{~N} / \mathrm{ha}$ and $4.0 \mathrm{t} / \mathrm{ha}+30 \mathrm{~kg} \mathrm{~N} / \mathrm{ha}$. PM applied $6.0 \mathrm{t} / \mathrm{ha}$ and $4.0 \mathrm{t} / \mathrm{ha}$ gave significantly lower number of panicles $/ \mathrm{m}^{2}$ than all the other treatments. Stover yield was similar for all the treatments but grain yield was significantly lower under sole $\mathrm{PM}$ than 90-60-60 and 2.0 t/ha PM + 22.5-15-15 kg N: $\mathrm{P}_{2} \mathrm{O}_{5}: \mathrm{K}_{2} \mathrm{O} / \mathrm{ha}$. As photosynthesis is enhanced the greener the leaves become. Hence higher SPAD values mean high production of photosynthates. Higher SPAD values for sole mineral fertilizer and mineral/organic fertilizer combinations partly explains higher number of panicles/plant and number of panicles $/ \mathrm{m}^{2}$ than sole poultry manure treatments. Availability of photosynthates may enhance and sustain tiller production which may result in differences in grain yield.

Table 2. Initial soil properties.

\begin{tabular}{lllllcccccc}
\hline \multirow{2}{*}{ Depth (cm) } & \multirow{2}{*}{ Soil H } & TC & OM & TN & Avail. P & Ca & Mg & K & EA & ECEC \\
\cline { 2 - 10 } & & $(\mathbf{g} / \mathbf{k g})$ & & & $\left(\mathbf{m g k g}^{-1}\right)$ & & 0.30 & 0.75 & 4.85 \\
\hline $0-20$ & 4.9 & 7.5 & 11.3 & 0.8 & 8.5 & 2.30 & 1.40 & 0 & \\
\hline
\end{tabular}

EA:-exchangeable acidity

Table 4. Effect of treatment on selected yield parameters in 2010.

\begin{tabular}{|c|c|c|c|}
\hline Treatments & Height (cm) & Number of panicles/plant & Grain yield (t/ha) \\
\hline $6 \mathrm{t} / \mathrm{ha} \mathrm{PM}$ & 59 & 2.7 & 3.3 \\
\hline $4 \mathrm{t} / \mathrm{ha} \mathrm{PM}$ & 58 & 3.0 & 3.3 \\
\hline $4 \mathrm{t} / \mathrm{ha} \mathrm{PM}+30 \mathrm{~kg} \mathrm{~N} / \mathrm{ha}$ & 58 & 2.7 & 3.7 \\
\hline $2 \mathrm{t} / \mathrm{ha} \mathrm{PM}+22.5-15-15 \mathrm{~kg} \mathrm{~N}: \mathrm{P}_{2} \mathrm{O}_{5}: \mathrm{K}_{2} \mathrm{O} / \mathrm{ha}$ & 59 & 2.7 & 4.2 \\
\hline $90-60-60 \mathrm{~kg} \mathrm{~N}: \mathrm{P}_{2} \mathrm{O}_{5}: \mathrm{K}_{2} \mathrm{O} / \mathrm{ha}$ & 60 & 3.0 & 3.3 \\
\hline $\operatorname{LSD}(0.05)$ & 4.6 & 1.1 & 1.9 \\
\hline
\end{tabular}

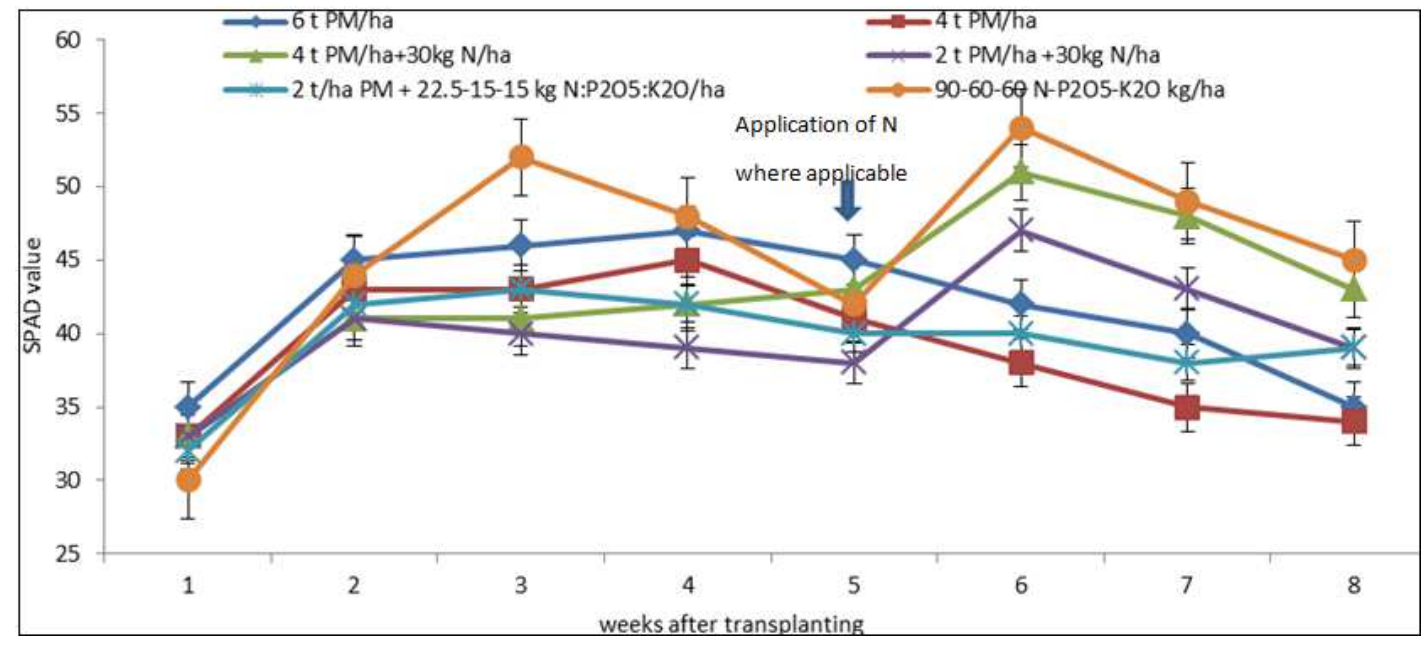

Figure 1. Effect of treatments on changes in SPAD values with time. 
Table 5. Effect of treatments on rice growth and yield in 2011.

\begin{tabular}{|c|c|c|c|c|c|c|}
\hline Treatment & Plant height $(\mathbf{c m})$ & $\begin{array}{l}\text { No. of } \\
\text { stands } / \mathbf{m}^{2}\end{array}$ & $\begin{array}{l}\text { Number of } \\
\text { panicles/plant }\end{array}$ & $\begin{array}{l}\text { No. of } \\
\text { panicles/m2 }\end{array}$ & $\begin{array}{l}\text { Stover yield } \\
(\mathrm{t} / \mathrm{ha})\end{array}$ & $\begin{array}{l}\text { Grain yield } \\
(\mathrm{t} / \mathrm{ha})\end{array}$ \\
\hline $6 \mathrm{t} / \mathrm{ha} \mathrm{PM}$ & $131 \mathrm{a}$ & $25.0 \mathrm{a}$ & $2.7 \mathrm{~b}$ & $185 \mathrm{c}$ & $5.7 \mathrm{a}$ & $4.7 \mathrm{~b}$ \\
\hline 4 t/ha PM & $133 \mathrm{a}$ & $25.0 \mathrm{a}$ & $3.0 \mathrm{~b}$ & $200 \mathrm{c}$ & $4.5 \mathrm{a}$ & $4.8 \mathrm{~b}$ \\
\hline $4 \mathrm{t} / \mathrm{ha} \mathrm{PM}+30 \mathrm{~kg} \mathrm{~N} / \mathrm{ha}$ & $133 a$ & $25.0 \mathrm{a}$ & $3.7 \mathrm{ab}$ & $235 \mathrm{~b}$ & $5.2 \mathrm{a}$ & $6.1 \mathrm{ab}$ \\
\hline $2 \mathrm{t} / \mathrm{ha} \mathrm{PM}+30 \mathrm{~kg} \mathrm{~N} / \mathrm{ha}$ & $132 \mathrm{a}$ & $25.0 \mathrm{a}$ & $3.7 \mathrm{ab}$ & $235 b$ & $5.3 \mathrm{a}$ & $5.3 \mathrm{ab}$ \\
\hline $\begin{array}{l}2 \mathrm{t} / \mathrm{ha} \mathrm{PM}+22.5-15-15 \mathrm{~kg} \\
\mathrm{~N}: \mathrm{P}_{2} \mathrm{O}_{5}: \mathrm{K}_{2} \mathrm{O} / \mathrm{ha}\end{array}$ & $134 \mathrm{a}$ & $25.0 \mathrm{a}$ & $4.3 \mathrm{a}$ & $265 \mathrm{a}$ & $5.6 \mathrm{a}$ & $6.4 \mathrm{a}$ \\
\hline $90-60-60 \mathrm{~kg} \mathrm{~N}: \mathrm{P}_{2} \mathrm{O} 5:{ }_{\mathrm{K} 2 \mathrm{O}} / \mathrm{ha}$ & $132 \mathrm{a}$ & $25.0 \mathrm{a}$ & $4.7 \mathrm{a}$ & $285 \mathrm{a}$ & $5.9 \mathrm{a}$ & $6.5 \mathrm{a}$ \\
\hline
\end{tabular}

Within a column figures followed by the same letters are not significantly different by a margin of the standard error.

\subsection{2: Residual Effect of Treatments}

\subsubsection{Residual Effect of Treatments on SPAD Values}

In 2012 changes in SPAD value during the growth of the plants are presented in Figure 2. SPAD values were similar in the second week due to application of $10 \mathrm{~kg} \mathrm{~N} / \mathrm{ha}$ to all plots. After the second week SPAD values started declining but at different rates. SPAD values fell to the lowest level in the fifth week during which additional $20 \mathrm{~kg} \mathrm{~N} / \mathrm{ha}$ was applied to all plots. This raised the SPAD values of plants growing on plots that earlier received $4.0 \mathrm{t} / \mathrm{ha}$ or $6.0 \mathrm{t} / \mathrm{ha} \mathrm{PM}$ to over 45 in the sixth week. SPAD values again started declining after the sixth week showing similar trend as observed between the second and fifth weeks. Plants growing on plots that received 6 t/ha PM had SPAD values above 40 up to the eighth week of growth. This was followed by plants on plots that received 4 t/ha PM showing values above 35 . The residual effect of mineral fertilizer was less effective in maintaining high levels of SPAD values. SPAD values fell to below 25 for plants growing on plots that received only mineral fertilizer (Figure 2 ). Gradual release of nutrient over a longer period, especially nitrogen, by the manure explains the observed trend. Higher SPAD values

\subsubsection{Residual Effect of Treatments on Yield Components and Grain Yield}

The residual effects of each treatment on yield components are presented in Table 6 . Number of panicles/plant and number of panicles $/ \mathrm{m}^{2}$ were significantly higher for $6.0 \mathrm{t} / \mathrm{ha}$ $\mathrm{PM}, 4.0 \mathrm{t} / \mathrm{ha} \mathrm{PM}$ and $4.0 \mathrm{t} / \mathrm{ha} \mathrm{PM}+30 \mathrm{~kg} \mathrm{~N} / \mathrm{ha}$ than $2 \mathrm{t} / \mathrm{ha} \mathrm{PM}$ $+22.5-15-15 \mathrm{~kg} \mathrm{~N}: \mathrm{P}_{2} \mathrm{O}_{5}: \mathrm{K}_{2} \mathrm{O} / \mathrm{ha}$ and $90-60-60 \mathrm{~kg} \mathrm{~N}$ : $\mathrm{P}_{2} \mathrm{O}_{5}: \mathrm{K}_{2} \mathrm{O} /$ ha but similar to $2.0 \mathrm{t} / \mathrm{ha} \mathrm{PM}+30 \mathrm{~kg} \mathrm{~N} / \mathrm{ha}$. Poultry manure at $6.0 \mathrm{t} / \mathrm{ha}, 4.0 \mathrm{t} / \mathrm{ha}$ and $4.0 \mathrm{t} / \mathrm{ha}+30 \mathrm{~kg} \mathrm{~N} / \mathrm{ha}$ gave significantly higher grain yield than the other treatments $(2$ $\mathrm{t} / \mathrm{ha} \mathrm{PM}+30 \mathrm{~kg} \mathrm{~N} / \mathrm{ha}, 2 \mathrm{t} / \mathrm{ha} \mathrm{PM}+22.5-15-15 \mathrm{~kg} \mathrm{~N}: \mathrm{P}_{2} \mathrm{O}_{5}$ : $\mathrm{K}_{2} \mathrm{O} / \mathrm{ha}$ and 90-60-60 kg N: $\mathrm{P}_{2} \mathrm{O}_{5}: \mathrm{K}_{2} \mathrm{O} / \mathrm{ha}$ ). This implies that at $4.0 \mathrm{t} / \mathrm{ha} \mathrm{PM}$ and above, optimum grain yield can be obtained. Organic fertilizer (poultry manure) showed a better residual effect than mineral fertilizer. This observation supports the findings of several authors $[4 ; 8 ; 9]$. PM is therefore an important source of plant nutrient for effective rice production for poor resource farmers.

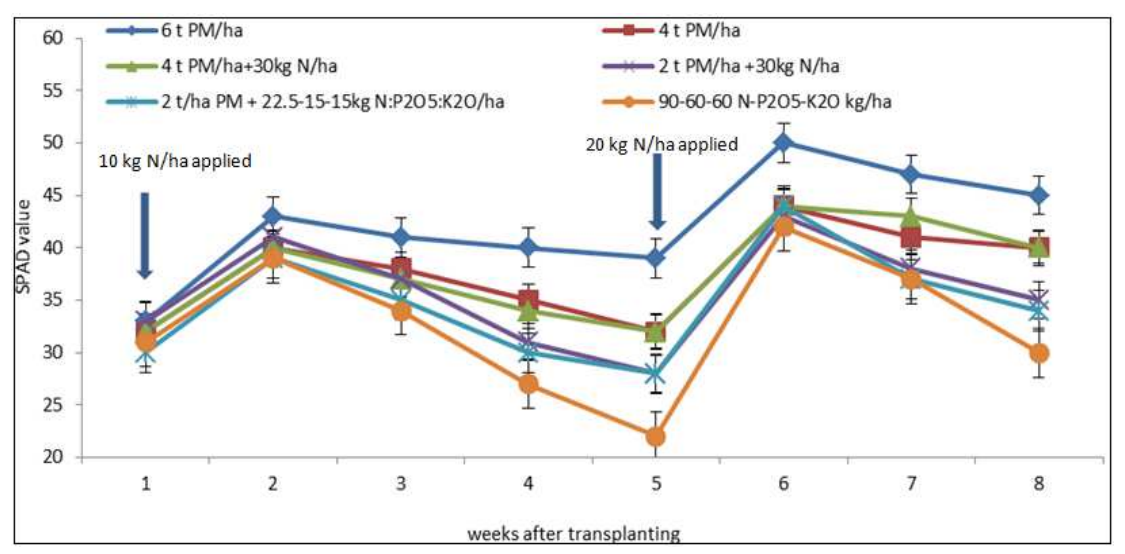

Figure 2. Residual effects on changes in SPAD values with time.

Table 6. Residual effect of treatments on rice yield.

\begin{tabular}{|c|c|c|c|c|c|c|}
\hline Treatment & Plant height (cm) & No. of $\operatorname{tand} / \mathrm{m} 2$ & $\begin{array}{l}\text { Number of } \\
\text { panicles/plant }\end{array}$ & $\begin{array}{l}\text { No. of } \\
\text { panicles/m2 }\end{array}$ & $\begin{array}{l}\text { Stover yield } \\
(\mathrm{t} / \mathrm{ha})\end{array}$ & $\begin{array}{l}\text { Grain yield } \\
\text { (t/ha) }\end{array}$ \\
\hline $6 \mathrm{t} / \mathrm{ha} \mathrm{PM}$ & $125 \mathrm{a}$ & $25.0 \mathrm{a}$ & $3.0 \mathrm{a}$ & $200 \mathrm{a}$ & $6.8 \mathrm{a}$ & $5.8 \mathrm{a}$ \\
\hline $4 \mathrm{t} / \mathrm{ha} \mathrm{PM}$ & $122 \mathrm{a}$ & $24.3 \mathrm{a}$ & $3.0 \mathrm{a}$ & $194 \mathrm{a}$ & $6.4 \mathrm{ab}$ & $5.3 \mathrm{ab}$ \\
\hline $4 \mathrm{t} / \mathrm{ha} \mathrm{PM}+30 \mathrm{~kg} \mathrm{~N} / \mathrm{ha}$ & $121 \mathrm{a}$ & $24.3 \mathrm{a}$ & $3.0 \mathrm{a}$ & $194 a$ & $6.7 \mathrm{a}$ & $5.6 \mathrm{a}$ \\
\hline $2 \mathrm{t} / \mathrm{ha} \mathrm{PM}+30 \mathrm{~kg} \mathrm{~N} / \mathrm{ha}$ & $121 \mathrm{a}$ & $24.7 \mathrm{a}$ & $2.7 \mathrm{ab}$ & $183 \mathrm{ab}$ & $5.8 \mathrm{bc}$ & $4.6 c$ \\
\hline $\begin{array}{l}2 \mathrm{t} / \mathrm{ha} \mathrm{PM}+22.5-15-15 \mathrm{~kg} \\
\mathrm{~N}: \mathrm{P}_{2} \mathrm{O}_{5}: \mathrm{K}_{2} \mathrm{O} / \mathrm{ha}\end{array}$ & $122 \mathrm{a}$ & $24.7 \mathrm{a}$ & $2.3 b$ & $163 b$ & $5.7 \mathrm{bc}$ & $4.7 \mathrm{bc}$ \\
\hline
\end{tabular}

Within a column figures followed by the same letters are not significantly different by a margin of the standard error. 


\subsection{Mean Grain Yield}

Mean grain yield for the three years is presented in Figure 3. The mean grain yield for the treatments $4 \mathrm{t} / \mathrm{ha} \mathrm{PM}+30 \mathrm{~kg}$ $\mathrm{N} / \mathrm{ha}$ and 2 t/ha PM + 22.5-15-15 kg N: P2O5: K2O/ha were significantly higher than all the other treatments. Particularly the $4 \mathrm{t} / \mathrm{ha} \mathrm{PM}+30 \mathrm{~kg} \mathrm{~N} / \mathrm{ha}$ treatment gave consistent grain yield of above $5.0 \mathrm{t} / \mathrm{ha}$ for 2011 and 2012. Mineral fertilizer and poultry manure combinations was more efficient in increasing rice yield.

\section{Conclusion}

Poultry manure is a cheaper and an alternative fertilizing material that can enhance rice production. Integrating poultry manure and mineral fertilizer provides a more efficient means of improving and sustaining rice yield. $4.0 \mathrm{t} / \mathrm{ha} \mathrm{PM}+30 \mathrm{~kg}$ $\mathrm{N} / \mathrm{ha}$ and $2 \mathrm{t} / \mathrm{ha} \mathrm{PM}+22.5-15-15 \mathrm{~kg} \mathrm{~N}: \mathrm{P}_{2} \mathrm{O}_{5}: \mathrm{K}_{2} \mathrm{O} /$ ha gave a significantly higher mean yield for the 3 years. Generally all the combinations gave similar grain yield as $90-60-60 \mathrm{~kg} \mathrm{~N}$ : $\mathrm{P}_{2} \mathrm{O}_{5}: \mathrm{K}_{2} \mathrm{O} /$ ha.

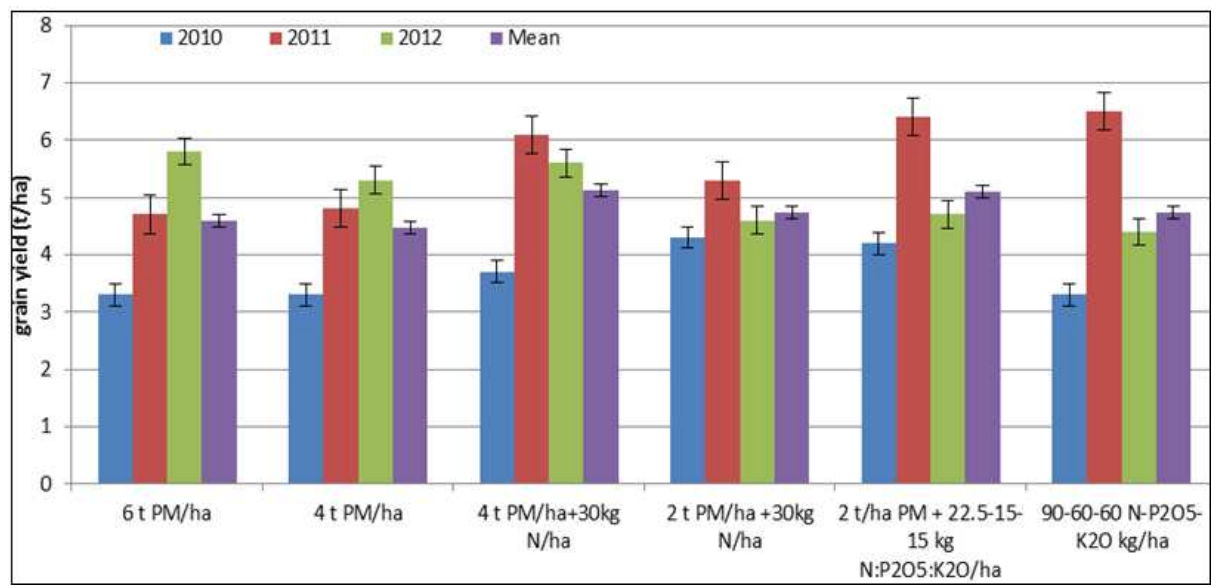

Figure 3. Mean yearly grain yield for the various treatments.

\section{Acknowledgments}

The authors are grateful for the funds received from Japan International Research Center for Agricultural Sciences as an out source contract for the Study on "Improvement of Soil Fertility with Use of Indigenous Resources in Rice Systems of sub-Sahara Africa" with Dr. Satoshi Tobita as Project Leader . We also wish to thank technicians and all staff at Soil Research Institute laboratory for their assistance.

\section{References}

[1] Susumu S. Abe, M. Moro Buri, Roland N. Issaka, Paul Kiepe and Toshiyuki Wakatsuki. 2010. Soil Fertility Potential for Rice Production in West African Lowlands. JARQ. 44 (4), 343 $-355$

[2] Buri, M. M., Iassaka, R. N., Fujii , H. and Wa-katsuki, T. 2009 Comparison of Soil Nutrient status of some Rice growing Environments in the major Agro-ecological zones of Ghana. International Journal of Food, Agriculture \& Environment Vol. 8 (1): $384-388$

[3] Buri, M. M., Issaka, R. N., Wakatsuki, T. and Otoo, E. (2004) Soil organic amendments and mineral fertilizers: Options for sustainable lowland rice production in the Forest agro-ecology of Ghana. Agriculture and Food Science Journal of Ghana. Vol., 3, 237-248.

[4] Senayah J. K., Issaka R. N. and Dedzoe, C. D. 2008.
Characteristics of Major Lowland Rice-growing Soils in the Guinea Savanna Voltaian Basin of Ghana. Agriculture and Food Science Journal of Ghana. Vol. 6. P 445-458

[5] Issaka, R. N., Buri, M. M., Tobita, S., Nakamura, S. and Owusu-Adjei, E. 2011. Indigenous Fertilizing Materials to Enhance Soil Productivity in Ghana. In Soil Fertility (editor: Joann K. Whalen) Improvement and Integrated Nutrient Management: A Global Perspective. Published by InTech, Janeza Trrdine 9, 51000 Rijeka, Croatia. ISBN 978-953-307-945-5

[6] Suzuki, A. (1997). Fertilization of rice in Japan. Japan FAO Association, Tokyo, Japan

[7] Myint, A. K., Yamakawa, T., Kajihara, Y. and Zenmyo, T. 2010. Application of different organic and mineral fertilizers on the growth, yield and nutrient accumulation of rice in a Japanese ordinary paddy field. Science World Journal Vol 5 (No 2) Pp 47-54

[8] Ohyama, N., Katono, M. \& Hasegawa, T. (1998). Effects of long term application of organic materials to the paddy field originated form Aso volcanic ash on the soil fertility and rice growth. I. Effects on the rice growth and nutrient uptake for the initial three years. Proceeding of Faculty of Agriculture, Kyushu Tokai University, 17:9-24. (In Japanese with English summary)

[9] Dedzoe C. D., Senayah J. K., Asubonteng K. O. and Otoo E. 1997. Characterization of inland valleys in Ghana: A semi-detailed study of the Mankran system in Ashanti Region. In Efficient Soil and Water Management: A Prerequisite for Sustainable Agriculture. Proc. $14^{\text {th }}$ and $15^{\text {th }}$ Annual General Meeting of the Soil Science Society of Ghana. 
[10] Mclean, E. O. 1982. Soil pH and lime requirement. In Page, A.L., Miller, R.H. and Keaney, D. R. (eds). Methods of Soil Analysis. Number 9 Part 2, Am. Soc. of Agron.

[11] Walkley, A. and Black, I.A. 1934. An examination of the method for determining soil organic matter and proposed modification of the chromic acid titration method. Soil Sci. 37:29-38.

[12] Bremner, D.C. and Mulvaney, J.M. 1982. Total nitrogen. In
Page, A.L., Miller, R. H. and Keaney, D.R. (eds). Methods of Soil Analysis. Number 9 Part 2, Am. Soc. of Agron.

[13] Bray, R. H. and Kurtz, L.T. 1945. Determination of total, organic and available forms of phosphorus in soils. Soil Sci. 59:39-45.

[14] Thomas, G.W. 1982. Exchangeable cations. In Page, A.L., Miller, R.H. and Keaney, D.R. (eds). Methods of Soil Analysis. Number 9, Part 2. Am. Soc. of Agron. 